\title{
MANAGING STRATEGY
}

Cliff Bowman

and

David Asch 
(C) Cliff Bowman and David Asch 1996

All rights reserved. No reproduction, copy or transmission of this publication may be made without written permission.

No paragraph of this publication may be reproduced, copied or transmitted save with written permission or in accordance with the provisions of the Copyright, Designs and Patents Act 1988, or under the terms of any licence permitting limited copying issued by the Copyright Licensing Agency, 90 Tottenham Court Road, London W1P 9HE.

Any person who does any unauthorised act in relation to this publication may be liable to criminal prosecution and civil claims for damages.

First published by MACMILLAN PRESS LTD

Houndmills, Basingstoke, Hampshire RG21 6XS and London

Companies and representatives

throughout the world

ISBN 978-0-333-60888-3 ISBN 978-1-349-24381-5 (eBook)

DOI 10.1007/978-1-349-24381-5

A catalogue record for this book is available from the British Library.

Transferred to digital printing 2002 


\section{Contents}

List of Figures and Tables vii

Preface ix

1 Introduction 1

Introduction 1

The content of strategy 1

Strategy processes 3

Personal preferences for particular strategy outcomes 10

Plan of the book 13

2 Analysing the Competitive Environment 15

Introduction 15

What markets are we competing in? 15

Analysing the structure of the industry 18

Identifying key trends in the industry 23

Analysing the wider environment 27

3 Competitive Strategy 34

Introduction 34

Porter's generic strategies 34

The strategy compass $\quad 37$

Analysing competitive position 48

Strategic groups and the strategy compass 54

4 Skills and Resources 56

Introduction 56

Issues in assessing skills and resources 57

Analysis of management and functions 59

Assessment of resources and the development of capabilities 66

Appendix: Summary of some financial ratios, their calculation and interpretation $\mathbf{7 0}$

5 Strategy, Structure and Systems 72

Introduction 72

Organisational structure: some basic concepts

72

Linking strategy, structure and process 76

Coping with diversity 83 
6 Strategy and Culture 85

Introduction 85

Culture and strategy 85

Realised strategy and performance 96

7 Managing Strategic Change 97

Introduction $\quad 97$

Culture and strategic change 97

The role of the 'mission statement' 100

Using the status quo to change the status quo 105

Identifying barriers to change 114

8 Managing Corporate Strategy 119

Introduction 119

Basic choices in corporate strategy 120

Diversification strategies 122

Portfolio approaches to corporate strategy 129

Horizontal strategies 134

Synergy in corporations 137

Routes to growth 139

Strategy, structure and strategic styles 146

International corporate strategy 150

9 Managing Strategy in Not for Profit Organisations 157

Introduction 157

Comparing firms and NFPs 158

Power structures in NFPs 163

Managing NFPs 167

Conclusion 173

References $\quad 175$

Index 179 


\section{List of Figures and Tables}

Figures

$1.1 \quad$ Level of strategy 2

1.2 Strategy process outcomes 4

1.3 Zones of strategy debate 6

1.4 Ownership of the strategy process 9

2.1 The five competitive forces 18

$2.2 \quad$ Key issue matrix 29

2.3 Issues in environmental appraisal 31

3.1 The strategy compass 37

3.2 Competing on price 39

3.3 Competitor response to price competition 39

3.4 Competing by adding perceived use value 41

3.5 Offering higher PUV at higher prices 46

3.6 Dimensions of perceived use value 49

3.7 Comparative dimensions of perceived use value $\quad 50$

3.8 The producer matrix 52

3.9 Combining the strategy compass with the producer matrix 52

4.1 Factors that influence a manager in defining strengths and weaknesses 58

$5.1 \quad$ Functional organisation 73

5.2 Main contingent variables 79

5.3 Task, environment and structure 81

6.1 Culture and strategy 86

7.1 Example of a mission statement 102

7.2 Subunit mission statements 104

7.3 Mission statement for the Wilshire Reporter Group 106

7.4 Actions to achieve mission 107

$\begin{array}{lll}7.5 & \text { Management structure of a regional newspaper - structure A } & 108\end{array}$

7.6 Achieving the mission 110

7.7 A regional newspaper - structure B 111

7.8 A regional newspaper - structure C 111

7.9 Forcefield analysis 115

8.1 Options for growth 122

8.2 Sequence of value chains: a value system 123

8.3 Sequences of value chains: parallel value system 126

8.4 Growth share matrix 130

8.5 Tangible relationships in a diversified firm 137

8.6 Post-acquisition integration 141 
8.7 Strategic management styles 148

8.8 Multinational corporation 152

8.9 Global corporation 153

8.10 Global integration and local responsiveness 154

8.11 Developing appropriate international strategies 154

8.12 Transnational corporation 155

$9.1 \quad \mathrm{NFP} / \mathrm{NI} /$ private sector objectives $\quad 171$

\section{Tables}

9.1 Summary of four decision-making models 166

9.2 Some elements of the private and public domains 174 


\section{Preface}

Since we first started researching and writing about strategic management over ten years ago the topic has developed significantly. In tandem with such developments we have seen an increasing degree of complexity in the business world coupled with a rate of change in organisations that was probably unimaginable over a decade ago.

This poses a problem for authors with regard to what to include in or exclude from a book like this since the literature in the field is now more sophisticated and more comprehensive. Our experience of teaching MBAs and managers is that many conventional texts are too academic, too long (though not necessarily comprehensive) and of little practical value. As a consequence we have decided to try a much more focused approach based not only on some new ideas concerning the content and process of strategy but also on some empirical findings in the area. We believe that this blend of new ideas and empiricism is preferable to merely rehearsing a range of theories. So the focus of the book is on 'doing' strategy and it is designed to be more action orientated.

Strategic management is often used as a final integrating unit in many advanced business and management courses because of a recognition that a 'strategic perspective' is a desirable attribute for all levels of management. This book is primarily aimed at managers who require further insights into the strategy of their organisation. It will also be appropriate for postgraduate and final-year undergraduate strategic management courses.

We would like to thank Eric Cassells for his valuable contribution to Chapter 8, 'Managing Corporate Strategy', and Frances Thomas for typing and tidying up the drafts of the chapters.

ClifF Bowman

DAVID ASCH 